\title{
Anaerobic co-digestion of hatchery waste and wastewater to produce energy and biofertilizer - Batch phase
}

\author{
Juliana M. Matter ${ }^{1}$, Mônica S. S. de M. Costa ${ }^{1}$, Luiz A. de M. Costa ${ }^{1}$, \\ Dercio C. Pereira ${ }^{1}$, Amarílis de Varennes $^{2} \&$ Dinéia Tessaro $^{3}$ \\ ${ }^{1}$ Universidade Estadual do Oeste do Paraná/Programa de Pós-Graduação em Engenharia Agrícola. Cascável, PR. E-mail: juli_matter@hotmail.com; \\ monicasarollisilva@gmail.com (Corresponding author); lmendo@ig.com.br; dercioceri@gmail.com \\ ${ }^{2}$ Universidade de Lisboa/Instituto Superior de Agricultura. Lisboa, Portugal. E-mail: amdevarennes@gmail.com \\ ${ }^{3}$ Universidade Tecnológica Federal do Paraná/Campus de Dois Vizinhos. Dois Vizinhos, PR. E-mail: ditessaro@yahoo.com.br
}

\section{Key words:}

biogas

methane

swine wastewater

slaughterhouse wastewater

\begin{abstract}
A B S T R A C T
Aiming to evaluate different wastewaters in the anaerobic co-digestion (ACoD) of hatchery wastes, a batch test was conducted in bench horizontal digesters. At the end of the process, the potential production of biogas and methane was calculated as well as the chemical composition (macro- and micronutrients) of the effluent and the concentrations of methane and carbon dioxide gas at 60 days. The monitoring of the process included observations of the reduction of the organic carbon, chemical oxygen demand, and total (TS) and volatile solids (VS), as well as the variation of $\mathrm{pH}$ and electrical conductivity (EC). The results showed that the mixing between the hatchery fresh waste and swine wastewater $\left(\mathrm{T}_{4}\right)$ and among fresh hatchery waste, water from the first anaerobic pond of the hatchery and swine wastewater $\left(\mathrm{T}_{5}\right)$ represent significant sources of renewable energy and thereby greater potential for biogas production (192.50 and 205.0 L biogas per kg of VS added to $\mathrm{T}_{4}$ and $\mathrm{T}_{5}$, respectively). The average concentration of methane in the biogas varied from 72 to $77 \%$ among the treatments. For all treatments, reductions were observed in TS and VS and increases in $\mathrm{pH}$ and EC. It was concluded that the energy recovery from hatchery wastes is favoured by the addition of swine wastewater in the ACoD process.
\end{abstract}

\section{Palavras-chave:}

biogás

metano

água residuária da suinocultura água residuária de frigorífico

\section{Co-digestão anaeróbia de resíduos de incubatório e águas residuárias para produção de energia e biofertilizante - Fase batelada}

\section{R E S U M O}

Visando avaliar diferentes águas residuárias na co-digestão anaeróbia de resíduos de incubatório foi realizado ensaio batelada conduzido em biodigestores horizontais de bancada. Ao final do processo foram determinados a produção e os potenciais de produção de biogás e de metano bem como a composição química (macro e micronutrientes) do efluente e a concentração de metano e gás carbônico aos 60 dias. O monitoramento do processo foi acompanhado pela redução de carbono orgânico, demanda química de oxigênio, sólidos totais e voláteis (ST e SV), além da variação do $\mathrm{pH}$ e da condutividade elétrica (CE). Os resultados obtidos revelaram que as misturas entre resíduo fresco de incubatório e água residuária de suinocultura - $\mathrm{ARS}\left(\mathrm{T}_{4}\right)$ e resíduo fresco de incubatório + água da primeira lagoa anaeróbia do incubatório + ARS $\left(\mathrm{T}_{5}^{4}\right)$ apresentaram os melhores potenciais de produção de biogás $(192,50$ e 205,0 L biogás por kg de SV adicionados, respectivamente). Aos 60 dias a concentração média de metano variou de 72 a $77 \%$ entre os tratamentos. Para todas as situações avaliadas observou-se redução de ST e SV e aumento do pH e da CE. Concluiu-se que a recuperação de energia dos resíduos de incubatório é favorecida pela adição de ARS em co-digestão anaeróbia. 


\section{INTRODUCTION}

The poultry industry has been developing rapidly, and consequently the entire production chain has tended to grows, from egg production to the slaughter of poultry for sale, generating significant amounts of waste at all stages of the raw material processing. The hatchery is the production unit where the embryonic development of fertile eggs occurs. There are losses during the incubation process making up the hatchery waste, which is composed of eggshells, infertile and unhatched eggs, chicks with malformations and stillbirths. Due to the large amount of wastes and the risk of environmental contamination imposed by them, there must be a correct destination for disposal (Emmoth et al., 2011). In this research, it is proposed to study the mixture of this material with other wastes, such as wastewater from agro-industrial process, a significant source of organic matter, which has the potential to be included as a raw material for co-digestion (Glatz et al., 2011). However, it is very important to conduct studies focused on the search for synergy or antagonism among wastes to establish the best combination possible to maximize the methane production, avoid inhibition processes and make the biogas plant profitable (Álvarez et al., 2010).

The anaerobic co-digestion of the poultry hatchery and wastewater ensure the production of renewable energy, given the degradation performed by the microorganisms (Larsen et al., 2013; Lijó et al., 2014), although studies on the process for obtaining renewable energy are still incipient.

Considering the above, this study aimed to verify the efficiency of the anaerobic co-digestion process in batch phase using poultry hatchery waste and different wastewaters generated in the production chains of poultry and swine through the evaluation of their potentials for the production of biogas, methane concentration and biofertilizer quality.

\section{MAterial AND Methods}

The experiment was conducted in Cascavel, Paraná in the Laboratory for Agro-Industrial Waste Analysis (LARA) of Universidade Estadual do Oeste do Paraná - UNIOESTE. For the testing the anaerobic co-digestion, a battery of 20 PVC digesters with 60 L capacity each was used. During the experiment, they remained horizontally supported on wood structures simulating a horizontal tubular digester. At the back of the digester was coupled a PVC pipe, by which the supply was provided. At the front of the digester there was a valve for effluent discharge. The gasometers were made with PVC pipe in which a tube of $300 \mathrm{~mm}$ was filled with water and another tube of $250 \mathrm{~mm}$ was upside down with its top closed. At the top, there was a valve for biogas escape. In the inner tube, a ruler of $30 \mathrm{~cm}$ was set to allow the measurement of the total biogas production.

The wastes were provided by an Agro-industrial Cooperative called COPACOL and were collected from units near the site of the experiment, and physicochemical characterization was performed (Table 1).

The inoculum used was confined cattle manure, accounting for $15 \%$ (dry matter) of the mixture. Treatments were established based on the origin of wastewater: slaughterhouse $\left(\mathrm{T}_{1}\right.$ and $\left.\mathrm{T}_{2}\right)$ and hatchery $\left(\mathrm{T}_{3}, \mathrm{~T}_{4}\right.$ and $\left.\mathrm{T}_{5}\right)$. Five mixtures were prepared using the hatchery waste: $\mathrm{T}_{1}(\mathrm{DHW}+\mathrm{WEQT})$ : drained hatchery waste + water from the equalizer tank of the poultry slaughterhouse; $\mathrm{T}_{2}$ (DHW + WAAP): drained hatchery waste + water from the first anaerobic pond of the slaughterhouse; $\mathrm{T}_{3}$ (FHW + WHAP): fresh hatchery waste + water from the first anaerobic pond of the hatchery; $\mathrm{T}_{4}(\mathrm{FHW}+\mathrm{SWW})$ : fresh hatchery waste + swine wastewater; $\mathrm{T}_{5}(\mathrm{FHW}+\mathrm{WHAP}+\mathrm{SWW})$ : fresh hatchery waste + water from the first anaerobic pond of the hatchery + swine wastewater. Each mixture treatment was repeated four times, totalizing 20 experimental units.

All mixtures were processed on an industrial blender to homogenize and reduce the particle size, especially that of eggshells. The different mixture compositions were calculated to obtain a substrate with $4 \%$ TS at the early process of anaerobic digestion. The testing lasted 176 days.

After installing the digesters, analyses were performed to characterize and evaluate their environmental performance. The total solids (TS) and volatile Solids (VS) in the influent and effluent of the digester were determined based on the methodology described by APHA (2012).

For the chemical analysis, all wastes were dried in a forced circulation oven at $50{ }^{\circ} \mathrm{C}$ to constant weight and then ground in a Wiley mill. The characterization of the samples was carried out by determining the $\mathrm{pH}$ with a bench potentiometer; organic

Table 1. Characteristics of the wastes used in the experiment

\begin{tabular}{|c|c|c|c|c|c|c|c|c|}
\hline \multirow{2}{*}{ Waste } & $\overline{C O D}$ & C & $\mathbf{N}$ & $P$ & $\bar{K}$ & $\mathrm{Ca}$ & $\overline{M g}$ & $S$ \\
\hline & \multicolumn{8}{|c|}{$\mathrm{mg} \mathrm{L}^{-1}$} \\
\hline FHW & 1622 & 60833 & 15272 & 0.8 & 3.0 & 371428 & 6360 & 3.0 \\
\hline DHW & 1217 & 45667 & 15972 & 0.8 & 1.7 & 400422 & 8444 & 4.5 \\
\hline Inoc & 6195 & 232367 & 15529 & 2.0 & 67.0 & 8022 & 12080 & 2.1 \\
\hline WET & 3088 & $<1000$ & 3780 & 11.0 & 67.4 & $<0.01$ & 3,26 & 452.6 \\
\hline WAAP & 838 & $<1000$ & 1500 & $<0.01$ & 59.7 & 9.6 & $<0.01$ & 386.9 \\
\hline WHAP & 851 & $<1000$ & 1500 & $<0.01$ & 93.6 & 24.0 & 2.0 & 431.8 \\
\hline \multirow[t]{3}{*}{ SWW } & 7813 & 4050 & 44690 & 500.4 & 528.3 & 588.1 & 321.4 & 1560 \\
\hline & $\mathrm{Fe}$ & $\mathrm{Zn}$ & $\mathrm{Cu}$ & ST & SV & \multirow{2}{*}{$\mathrm{pH}$} & \multirow{2}{*}{\multicolumn{2}{|c|}{$\begin{array}{c}\text { CE } \\
\left(\mathrm{dS} \mathrm{m}^{-1} \text { a } 25^{\circ} \mathrm{C}\right)\end{array}$}} \\
\hline & \multicolumn{3}{|c|}{$\mathrm{mg} \mathrm{L}^{-1}$} & \multicolumn{2}{|c|}{$\%$} & & & \\
\hline FHW & 65.2 & 22.0 & 18.8 & 73.9 & 17.1 & 7.9 & \multicolumn{2}{|c|}{3400} \\
\hline DHW & 54.6 & 33.4 & 20.0 & 90.8 & 16.9 & 6.9 & \multicolumn{2}{|c|}{487} \\
\hline Inoc & 23689 & 73.1 & 79.4 & 32.2 & 78.8 & 6.8 & \multicolumn{2}{|c|}{1336} \\
\hline WET & $<0.01$ & 1.0 & $<0.01$ & 0.2 & 77.3 & 6.1 & \multicolumn{2}{|c|}{1279} \\
\hline WAAP & $<4.5$ & 1.2 & $<0.01$ & 0.1 & 30.2 & 6.4 & \multicolumn{2}{|c|}{1.085} \\
\hline WHAP & 7.6 & 0.7 & $<0.01$ & 0.1 & 86.9 & 7.4 & \multicolumn{2}{|c|}{668.2} \\
\hline SWW & 76.7 & 17.2 & 34.1 & 0.6 & 49.0 & 7.2 & \multicolumn{2}{|c|}{7450} \\
\hline
\end{tabular}

COD - Chemical oxygen demand; FHW - Fresh hatchery waste; DHW - Drained hatchery waste; Inoc - Inoculum; WET - Water from the equalizer tank of the poultry slaughterhouse; WAAP - Water from the slaughterhouse's first anaerobic pond; WHAP - Water from the hatchery's first anaerobic pond; SWW - Swine wastewater 
carbon (C) by the method of Walkley \& Black (Kiehl, 2010); nitrogen $(\mathrm{N})$ using the Kjeldahl distiller; phosphorus $(\mathrm{P})$ by spectrophotometry according to the methodology proposed by Malavolta et al. (1989); and potassium (K), calcium (Ca), magnesium $(\mathrm{Mg})$, zinc $(\mathrm{Zn})$, copper $(\mathrm{Cu})$, iron $(\mathrm{Fe})$ and manganese $(\mathrm{Mn})$ by atomic absorption after digestion in nitroperchloric acid (EMBRAPA, 2009). The COD analysis was performed according to the equation described by Kiehl (2010).

The daily biogas production in the anaerobic digesters was monitored by reading the vertical displacement of the ruler fixed in the gasometer. The values were submitted to a transformation equation and the result expressed in $\mathrm{m}^{3} \mathrm{~d}^{-1}$, according to Caetano (1985).

To obtain the expression for the biogas volume correction $\left(\mathrm{V}_{0}=\right.$ $\mathrm{V}_{1} / \mathrm{T}_{1} \times 272.0323$ ), the atmospheric pressure in Cascavel (Instituto Tecnológico Simepar, 2010) in the period was considered, which was a 9373.4-mm water column, plus the pressure read out from the gasometers (a 20.00-mm water column).

The analysis of the biogas composition was performed 60 days after supplying the digesters using gas chromatography to determine the concentrations of methane and carbon dioxide present in the biogas produced in the headspace. The sampling of biogas was performed with a special syringe for gas chromatography, and readings were performed in real time to avoid interference from atmospheric gases. The samples were analysed using a SHIMADZU GC-2010 Gas Chromatograph TCD with a Supel-Q PLOT ( $30 \times 0.53 \mathrm{~mm})$ fused silica column.

The biogas and methane potential production were obtained by dividing the total biogas or methane production in the testing period by the amount of substrate in the fresh or drained hatchery waste and adding the TS and VS.

The results obtained were subjected to an analysis of variance and treated using a factorial design with five treatments and two measurements (influent and effluent). The results were analysed by applying the Tukey test for the comparison of means at a 0.05 probability.

\section{Results AND Discussion}

Table 2 shows the potential biogas and methane production considering the possibilities of energy recovery in the slaughterhouse/agro-industry $\left(\mathrm{T}_{1}, \mathrm{~T}_{2}\right)$ or in the hatchery $\left(\mathrm{T}_{3}\right.$, $\mathrm{T}_{4}$ and $\mathrm{T}_{5}$ ).

The biogas/methane production potentials per $\mathrm{kg}$ of the added TS and VS are more reliable once the interference of the water content present in the biomass is eliminated (Orrico et al., 2007), and they reflect the amount and quality of the carbon that can be converted into energy (Orrico Júnior. et al., 2011). The energy recovery from the hatchery waste when considering the two wastewaters produced in the slaughterhouse $\left(\mathrm{T}_{1}\right.$ and $\mathrm{T}_{2}$ ) showed statistically the same biogas and methane potential productions (TS and VS). The water from the equalization tank and the effluent from the stabilization pond similarly showed the same performance upon co-digestion with drained hatchery waste. $\mathrm{T}_{2}$ showed considerable values for the production of biogas and methane per $\mathrm{kg}$ TS added, which may be due to the characteristics of the wastewater used in the co-digestion, i.e., the first anaerobic pond water from the poultry slaughterhouse, which probably had a microbiota with methanogenic bacteria that adapted easily to the substrate. This, coupled with the long period of material retention, promoted increased values of biogas and methane production.

In relation to the mixtures for energy recovery in the hatchery $\left(\mathrm{T}_{3}, \mathrm{~T}_{4}\right.$ and $\left.\mathrm{T}_{5}\right)$, it is possible to affirm that the use of swine wastewater favoured the anaerobic co-digestion process. $\mathrm{T}_{4}$ and $\mathrm{T}_{5}$ showed the highest biogas and methane productions in their accumulated values. The results also demonstrate that these two treatments had higher values for the potential production of methane and biogas per $\mathrm{kg}$ of substrate. This result may be related to the large potential for biogas generation from swine wastewater (Oliveira \& Duda, 2009).

The biogas production generated in the different treatments is shown in Figure 1.

The onset of biogas burning is a parameter that may be useful in the choice of substrate to be used for fermentation, since it is related to the amount of methane produced being sufficient to cause combustion. In this work, the burning point of biogas was different for each treatment. $\mathrm{T}_{1}$ showed continuous burning from the $19^{\text {th }}$ day, $\mathrm{T}_{2}$ - day $20, \mathrm{~T}_{3}$ - day $40, \mathrm{~T}_{4}$ - day 11 and $\mathrm{T}_{5}$ day 20 . The $\mathrm{T}_{4}$ treatment, besides receiving $15 \%$ inoculum from cattle manure, also has swine wastewater in its mixture, which contains a high organic load and VS that can easily undergo conversion to methane.

Table 2. Average potential biogas and methane production per kg of substrate, hatchery waste, TS and VS added and cumulative production

\begin{tabular}{|c|c|c|c|c|c|}
\hline Treatment $^{*}$ & Substrate & Waste & TS added & VS added & Cumulative production (L) \\
\hline \multicolumn{6}{|c|}{ Potential biogas production $\left(\mathrm{L} \mathrm{kg}^{-1}\right)$} \\
\hline $\mathrm{T}_{1}$ & $3.1 \mathrm{~b}$ & $56 \mathrm{a}$ & $88 \mathrm{ab}$ & $112 \mathrm{c}$ & $154 \mathrm{~b}$ \\
\hline $\mathrm{T}_{2}$ & $2.6 \mathrm{~b}$ & $47 \mathrm{a}$ & $100 \mathrm{a}$ & $112 \mathrm{c}$ & $130 \mathrm{~b}$ \\
\hline $\mathrm{T}_{3}$ & $3.2 \mathrm{~b}$ & $27 \mathrm{~b}$ & $65 \mathrm{~b}$ & $140 \mathrm{bc}$ & $160 \mathrm{~b}$ \\
\hline $\mathrm{T}_{4}$ & $6.7 \mathrm{a}$ & $56 a$ & $98 \mathrm{a}$ & $192 a b$ & $334 \mathrm{a}$ \\
\hline $\mathrm{T}_{5}$ & $6.2 \mathrm{a}$ & $53 \mathrm{a}$ & $82 a b$ & $205 a$ & $310 \mathrm{a}$ \\
\hline CV \% & 15.9 & 14.6 & 13.76 & 16.5 & 15.9 \\
\hline $\mathrm{T}_{1}$ & $2.2 \mathrm{~b}$ & $40 \mathrm{a}$ & $61 \mathrm{ab}$ & $80 \mathrm{~b}$ & $110 \mathrm{~b}$ \\
\hline $\mathrm{T}_{2}$ & $2.0 \mathrm{~b}$ & $37 \mathrm{a}$ & $78 \mathrm{a}$ & $88 \mathrm{~b}$ & $101 \mathrm{~b}$ \\
\hline $\mathrm{T}_{3}$ & $2.3 b$ & $20 \mathrm{~b}$ & $48 \mathrm{~b}$ & $103 b$ & $117 \mathrm{~b}$ \\
\hline $\mathrm{T}_{4}$ & $5.1 \mathrm{a}$ & $43 \mathrm{a}$ & $75 \mathrm{a}$ & $146 \mathrm{a}$ & $255 \mathrm{a}$ \\
\hline$T_{5}$ & $4.5 \mathrm{a}$ & $38 \mathrm{a}$ & $61 \mathrm{ab}$ & $150 \mathrm{a}$ & $226 \mathrm{a}$ \\
\hline CV \% & 14.6 & 13.8 & 15.7 & 16.6 & 14.8 \\
\hline
\end{tabular}

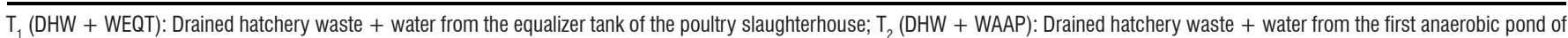
the slaughterhouse; $T_{3}\left(\right.$ FHW + WHAP): Fresh hatchery waste + water from the first anaerobic pond of the hatchery; $T_{4}($ FHW $+S W W)$ : Fresh hatchery waste + swine wastewater; $T_{5}$ (FHW + WHAP + SWW): Fresh hatchery waste + water from the first anaerobic pond of the hatchery + swine wastewater

Values in the same row followed by different letters were considered significantly different (ANOVA, Tukey test $p<0.05$ ) 


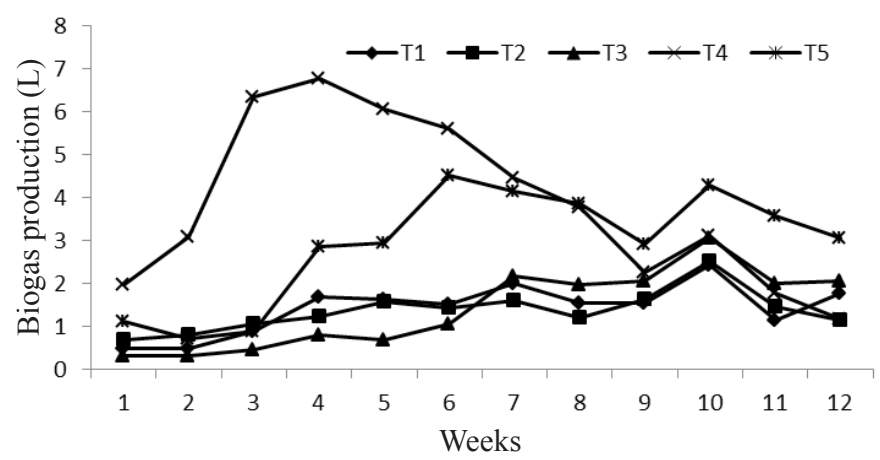

$\mathrm{T}_{1}$ (DHW + WEQT): Drained hatchery waste + water from the equalizer tank of the poultry slaughterhouse; $T_{2}$ (DHW + WAAP): Drained hatchery waste + water from the first anaerobic pond of the slaughterhouse; $T_{3}(\mathrm{FHW}+$ WHAP): Fresh hatchery waste + water from the first anaerobic pond of the hatchery; $\mathrm{T}_{4}(\mathrm{FHW}+\mathrm{SWW})$ : Fresh hatchery waste + swine wastewater $\mathrm{T}_{5}(\mathrm{FHW}+\mathrm{WHAP}+\mathrm{SWW})$ : Fresh hatchery waste + water from the first anaerobic pond of the hatchery + swine wastewater

Figure 1. Distribution of average production of biogas in batch digesters stocked with hatchery waste and agroindustrial wastewater

The biogas produced in the batch digesters was statistically evaluated for its contents of carbon dioxide and methane at day 60 of the experiment, but no significant differences were observed $(\mathrm{p}<0.05)$. The mean results for the percentages of $\mathrm{CH}_{4}$ and $\mathrm{CO}_{2}$ are shown in Figure 2.

Mandal et al. (1999) observed that the flame temperature of the gas gradually increases after the second week and then reaches a maximum value at the middle of the retention period, approximately 6 weeks, falling thereafter. This is because the percentage of methane in the biogas varies with the retention

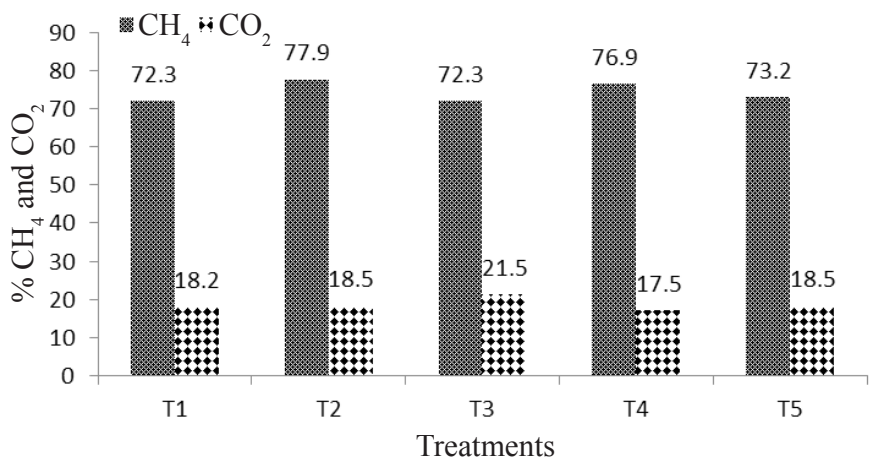

$\mathrm{T}_{1}(\mathrm{DHW}+\mathrm{WEQT})$ : Drained hatchery waste + water from the equalizer tank of the poultry slaughterhouse; $T_{2}$ (DHW + WAAP): Drained hatchery waste + water from the first anaerobic pond of the slaughterhouse; $\mathrm{T}_{3}(\mathrm{FHW}+\mathrm{WHAP})$ : Fresh hatchery waste + water from the first anaerobic pond of the hatchery; $\mathrm{T}_{4}(\mathrm{FHW}+\mathrm{SWW})$ : Fresh hatchery waste + swine wastewater $\mathrm{T}_{5}(\mathrm{FHW}+\mathrm{WHAP}+\mathrm{SWW})$ : Fresh hatchery waste + water from the first anaerobic pond of the hatchery + swine wastewater

Figure 2. Average contents of $\mathrm{CH}_{4}$ and $\mathrm{CO}_{2}$ in the biogas produced in the digesters operated with hatchery waste and agro-industrial wastewater after 60 days period. The values of $\mathrm{CH}_{4}$ analysed 60 days after the beginning of the present experiment ranged from 72 to $77 \%$, and this is probably the maximum concentration.

At the end of the process, the chemical composition of the effluent was determined, and the results are shown in Table 3.

It may not be possible to establish a standard for the quality of biofertilizers according to the origin of the wastewater used in the anaerobic co-digestion with hatchery wastes. By the results of the variance analysis, it can be observed that all of the biofertilizers showed similar and high concentrations of nutrients, but the micronutrient content may be higher when using particular soils and cultures. Thus, an environmental and safety recommendation is necessary. The comparison of the data with that of biofertilizers produced with other wastewaters by anaerobic co-digestion processes is not so useful because of the chemical characteristics of the mixtures, mainly the presence of hatchery wastes. However, it is important to mention that during the anaerobic digestion process, the concentration of nutrients is increased due to the reduction of the TS and VS by conversion into biogas, thus causing an increase in the concentration of the mineral fraction (Orrico Júnior. et al., 2010). It is also important to mention that during the anaerobic digestion process, there is a change of the $\mathrm{N}$ organic form into ammonium $\left(\mathrm{NH}_{4}\right)$, representing more than $60 \%$ of the TNK according to Costa et al. (2016a), and this is one of the forms in which plants can use this nutrient, so this process contributes to the improvement of the agronomic value of wastewaters.

The environmental performance of the anaerobic codigestion process was evaluated by the monitoring of the parameters shown in Table 4.

The analysis of variance revealed no interaction between the treatment and measurement (influent and effluent) for the $\mathrm{C}$ and COD variables. There was only a significant effect $(p<0.05)$ for lower values of $\mathrm{C}$ and COD from the early to the late process of anaerobic co-digestion (influent to effluent). Thus, there was decreased COD between the influent and effluent, on average $27.5 \%$. Regarding the other variables, the analysis of variance showed interactions between the treatments and measurements (influent and effluent).

For the $\mathrm{pH}$, all treatments showed higher values in the effluent compared to those in the early process (influent) ( $p<0.05)$. Quadros et al. (2010) observed an increase of $20 \%$ in the $\mathrm{pH}$ after the anaerobic digestion of goat and sheep wastes in a continuous reactor. The generation of hydroxyls due to organic compound degradation during anaerobic codigestion promotes the increase in $\mathrm{pH}$, and this is a parameter that is important to monitor in the process (Yang et al.,

Table 3. Contents of macro- and micronutrients in the effluents of the digesters in the batch phase

\begin{tabular}{|c|c|c|c|c|c|c|c|c|c|c|}
\hline \multirow{2}{*}{ Treatment $^{*}$} & $\mathrm{~N}$ & $\mathbf{P}$ & $K$ & $\mathrm{Ca}$ & $\mathrm{Mg}$ & $S$ & $\mathrm{Fe}$ & $\mathrm{Cu}$ & $\mathrm{Zn}$ & $\mathrm{Mn}$ \\
\hline & \multicolumn{6}{|c|}{$\overline{g^{-1}}$} & \multicolumn{4}{|c|}{$\mathrm{mg} \mathrm{L}^{-1}$} \\
\hline $\mathrm{T}_{1}$ & 28.1 & $17.1 \mathrm{ab}$ & $12.9 \mathrm{ab}$ & $169 \mathrm{~b}$ & $4.6 \mathrm{~b}$ & 30.0 & 7057 a & $42.0 \mathrm{~b}$ & $104 \mathrm{~b}$ & $0.16 a b$ \\
\hline $\mathrm{T}_{2}$ & 20.4 & $10.5 b$ & $8.1 a b$ & $264 a b$ & $4.3 \mathrm{~b}$ & 18.6 & $6163 a b$ & $27.1 \mathrm{~b}$ & $67 \mathrm{~b}$ & $0.12 a b$ \\
\hline $\mathrm{T}_{3}$ & 14.1 & $9.4 \mathrm{~b}$ & $6.1 \mathrm{~b}$ & $251 a b$ & $4.3 \mathrm{~b}$ & 19.8 & $3681 a b$ & $8.2 \mathrm{~b}$ & $70 \mathrm{~b}$ & $0.08 \mathrm{~b}$ \\
\hline $\mathrm{T}_{4}$ & 24.1 & $30.7 \mathrm{a}$ & $16.4 \mathrm{a}$ & $212 \mathrm{ab}$ & $6.8 \mathrm{a}$ & 21.2 & $3824 a b$ & $332.3 \mathrm{a}$ & $272 \mathrm{a}$ & $0.20 \mathrm{a}$ \\
\hline $\mathrm{T}_{5}$ & 16.7 & $9.9 \mathrm{~b}$ & $10.3 a b$ & $337 \mathrm{a}$ & $4.8 \mathrm{~b}$ & 12.6 & $1278 \mathrm{~b}$ & $57.1 \mathrm{~b}$ & $128 b$ & $0.09 a b$ \\
\hline CV & 41 & 69 & 52 & 34 & 23 & 53 & 68 & 147 & 73 & 49 \\
\hline
\end{tabular}

$\mathrm{T}_{1}(\mathrm{DHW}+\mathrm{WEQT})$ : Drained hatchery waste + water from the equalizer tank of the poultry slaughterhouse; $\mathrm{T}_{2}(\mathrm{DHW}+$ WAAP): Drained hatchery waste + water from the first anaerobic pond of the slaughterhouse; $T_{3}\left(F H W+\right.$ WHAP): Fresh hatchery waste + water from the first anaerobic pond of the hatchery; $T_{4}(F H W+S W W)$ : Fresh hatchery waste + swine wastewater; $T_{5}$ (FHW + WHAP + SWW): Fresh hatchery waste + water from the first anaerobic pond of the hatchery + swine wastewater

Values in the same row followed by different letters were considered significantly different (ANOVA, Tukey test $p<0.05$ ) 
Table 4. Values of total organic carbon, $\mathrm{COD}$, $\mathrm{pH}$, electrical conductivity, TS and VS in batch digesters

\begin{tabular}{|c|c|c|c|c|c|c|}
\hline \multirow{2}{*}{ Treatment $^{*}$} & C & COD & \multirow{2}{*}{ pH } & \multirow{2}{*}{$\begin{array}{c}\text { EC } \\
\text { dS } \mathrm{m}^{-1} \text { at } 25^{\circ} \mathrm{C}\end{array}$} & \multirow{2}{*}{\multicolumn{2}{|c|}{ VS }} \\
\hline & \multicolumn{2}{|c|}{$\mathrm{mg} \mathrm{L}^{-1}$} & & & & \\
\hline & & & \multicolumn{2}{|c|}{ Influent } & \multicolumn{2}{|c|}{$\%$} \\
\hline $\mathrm{T}_{1}$ & 143.9 & 3.8 & $6.6 \mathrm{eB}$ & 1.6 Db & $3.6 \mathrm{bcA}$ & $38.2 \mathrm{bA}$ \\
\hline $\mathrm{T}_{2}$ & 140.4 & 3.7 & $7.1 \mathrm{~dB}$ & $1.4 \mathrm{~dB}$ & $2.5 \mathrm{cA}$ & $44.4 \mathrm{aA}$ \\
\hline $\mathrm{T}_{3}$ & 119.8 & 3.2 & $7.7 \mathrm{aB}$ & $2.6 \mathrm{cB}$ & $6.6 \mathrm{abA}$ & $28.9 \mathrm{cA}$ \\
\hline $\mathrm{T}_{4}$ & 188.2 & 5.0 & $7.4 \mathrm{cB}$ & $8.0 \mathrm{aB}$ & $7.2 \mathrm{aA}$ & $38.9 \mathrm{bA}$ \\
\hline $\mathrm{T}_{5}$ & 154.7 & 4.1 & $7.5 \mathrm{bB}$ & $5.4 \mathrm{bB}$ & $8.7 \mathrm{aA}$ & $36.8 \mathrm{bA}$ \\
\hline Mean & $149.4 \mathrm{~A}$ & $4.0 \mathrm{~A}$ & & & & \\
\hline \multicolumn{7}{|c|}{ Effluent } \\
\hline $\mathrm{T}_{1}$ & 107.4 & 2.9 & $7.2 \mathrm{cA}$ & $5.6 \mathrm{dA}$ & $0.7 \mathrm{aB}$ & $34.3 \mathrm{aB}$ \\
\hline $\mathrm{T}_{2}$ & 111.0 & 3.0 & $7.2 \mathrm{cA}$ & $5.1 \mathrm{dA}$ & $0.7 \mathrm{aB}$ & $37.7 \mathrm{aB}$ \\
\hline $\mathrm{T}_{3}$ & 86.3 & 2.3 & $7.4 \mathrm{bA}$ & $9.5 \mathrm{cA}$ & $1.3 \mathrm{aB}$ & $23.3 \mathrm{bB}$ \\
\hline $\mathrm{T}_{4}$ & 130.7 & 3.5 & $7.8 \mathrm{aA}$ & $15.6 \mathrm{aA}$ & $1.8 \mathrm{aB}$ & $25.8 \mathrm{bB}$ \\
\hline $\mathrm{T}_{5}$ & 104.5 & 2.8 & $7.7 \mathrm{aA}$ & $13.4 \mathrm{bA}$ & $1.4 \mathrm{aB}$ & $19.0 \mathrm{bB}$ \\
\hline Mean & 108.0 B & $2.9 \mathrm{~B}$ & & & & \\
\hline
\end{tabular}

$\mathrm{T}_{1}(\mathrm{DHW}+\mathrm{WEQT})$ : Drained hatchery waste + water from the equalizer tank of the poultry slaughterhouse; $T_{2}$ (DHW + WAAP): Drained hatchery waste + water from the first anaerobic pond of the slaughterhouse; $\mathrm{T}_{3}(\mathrm{FHW}+$ WHAP): Fresh hatchery waste + water from the first anaerobic pond of the hatchery; $T_{4}$ (FHW + SWW): Fresh hatchery waste + swine wastewater;

$\mathrm{T}_{5}$ (FHW + WHAP + SWW): Fresh hatchery waste + water from the first anaerobic pond of the hatchery + swine wastewater

There was no interaction between the $C$ and $C O D$ variables. Regarding the other variables, lowercase letters compare treatments within each situation (influent or effluent), and capita letters compare the influent and effluent by the Tukey test at 0.05 significance

2015). Regarding the influent $\mathrm{pH}$, it is interesting to observe that treatments $\mathrm{T}_{1}$ and $\mathrm{T}_{2}$ that showed the lowest values also presented the lowest biogas potential productions. Zhai et al. (2015) concluded that the maximum methane production potential was obtained when the initial $\mathrm{pH}$ was 7.5 , considering the co-digestion of kitchen waste and cow manure.

Analysing the values of the electrical conductivity (EC), there are higher values in the effluent compared to those in the influent $(\mathrm{p}<0.05)$. This result may be associated with the salt solubilization during the process and the mineralization of organic matter (Massaccesia et al., 2013). The electrical conductivity indicates a certain degree of salinity in the effluent, which limits its use in agricultural irrigation, but not its use as fertilizer in a controlled manner (Silva et al., 2012).

Regarding the degrees of reduction of TS and VS, there were decreased levels between the influent and effluent. However, it is important to observe that the range of values of TS and VS between the influent and effluent may have been the effect of sedimentation, since the presence of eggshells makes the interpretation of these results difficult. Costa et al. (2016b) also reported difficulty in measuring the correlation between the TS and VS degradation depending on the biogas production in the anaerobic digestion of young bull manure with high TS content (between 6 and 8\%). The authors mention that the samples tend to become segregated, influencing the masses of TS and VS and thereby the data calculation.

\section{Conclusions}

1. The energy recovery from hatchery wastes is favoured by the addition of swine wastewater to the anaerobic co-digestion.

2. The anaerobic co-digestion promotes the production of a biofertilizer with high agronomic value, which must be recommended with environmental and safety patterns.

\section{Acknowledgements}

Authors thank COPACOL for the availability of wastes and wastewaters and Itaipu Binacional for the first author's scholarship.

\section{Literature Cited}

Álvarez, J. A.; Otero, L.; Lema, J. M. A methodology for optimising feed composition for anaerobic co-digestion of agro-industrial wastes. Bioresource Technology, v.101, p.1153-1158, 2010. https:// doi.org/10.1016/j.biortech.2009.09.061

APHA, AWWA, WEF. Standard methods for examination of water and wastewater. 22.ed. Washington: American Public Health Association, 2012, 1360p.

Caetano, L. Proposição de um sistema modificado para quantificação de biogás. Botucatu: FCA/UNESP, 1985. 75p. Dissertação Mestrado

Costa, M. S. S. de M.; Lorin, H. E. F.; Costa, L. A. de M.; Cestonaro, T.; Pereira, D. C.; Bernardi, F. H. Performance of four stabilization bioprocesses of beef cattle feedlot manure. Journal of Environmental Management, v.181, p.443-448, 2016a. https://doi.org/10.1016/j. jenvman.2016.07.003

Costa, M. S. S. de M.; Lucas Júnior, J. de; Costa, L. A. de M.; Orrico, A. C. A. A highly concentrated diet increases biogas production and the agronomic value of young bull's manure. Waste Management, v.48, p.521-527, 2016b. https://doi.org/10.1016/j.wasman.2015.09.038

EMBRAPA - Empresa Brasileira de Pesquisa Agropecuária. Manual de análises químicas de solos, plantas e fertilizantes. 2.ed. Brasília: EMBRAPA, 2009. 627p.

Emmoth, E.; Ottoson, J.; Albihn, A.; Belák, S.; Vinnerås, B. Ammonia disinfection of hatchery waste for elimination of single-stranded RNA viruses. Applied and Environmental Microbiology, v.77, p.3960-3966, 2011. https://doi.org/10.1128/AEM.02990-10

Glatz, P.; Miao, Z.; Rodda, B. Handling and treatment of poultry hatchery waste: A review. Journal Sustainability, v.3, p.216-237, 2011. https://doi.org/10.3390/su3010216

Instituto Tecnológico Simepar. Tecnologia e informações ambientais. Curitiba: SIMEPAR. 2010.

Kiehl, E. J. Novo fertilizantes orgânicos. 1.ed. Piracicaba: Ceres, 2010. 248p.

Larsen, A. C.; Gomes, B. M.; Gomes, S. D.; Zenatti, D. C.; Torres, D. G. B. Anaerobic co-digestion of crude glycerin and starch industry effluent. Engenharia Agrícola, v.33, p.341-352, 2013. https://doi. org/10.1590/S0100-69162013000200013

Lijó, L.; González-García, S.; Bacenetti, J.; Fiala, M.; Feijoo, G.; Lema, J. M.; Moreira, M. T. Life cycle assessment of electricity production in Italy from anaerobic co-digestion of pig slurry and energy crops. Renewable Energy, v.68, p.625-635, 2014. https://doi.org/10.1016/j. renene.2014.03.005

Malavolta, E.; Vitti, G. C.; Oliveira, S. A. Avaliação do estado nutricional das plantas: Princípios e aplicações. 1.ed. Piracicaba: Potafos, 1989. $201 \mathrm{p}$.

Mandal, T.; Kiran, B. A.; Mandal, N. K. Determination of the quality of biogas by flame temperature measurement. Energy Conversion \& Management, v.40, p.1225-1228, 1999. https://doi.org/10.1016/ S0196-8904(99)00009-6 
Massaccesia, L.; Sordi, A.; Micale, C.; Cucina, M.; Zadra, C.; Maria, F. di; Gigliotti, G. Chemical characterisation of percolate and digestate during the hybrid solid anaerobic digestion batch process. Process Biochemistry, v.48, p.1361-1367, 2013. https://doi.org/10.1016/j. procbio.2013.06.026

Oliveira, R. A. de; Duda, R. M. Tratamento de águas residuárias de suinocultura em reator anaeróbio operado em batelada sequencial. Revista Engenharia Sanitária e Ambiental, v.14, p.533-542, 2009. https://doi.org/10.1590/S1413-41522009000400013

Orrico, A. C. A.; Lucas Júnior, J. de; Orrico Júnior, M. A. P. Caracterização e biodigestão anaeróbia dos dejetos de caprinos. Engenharia Agrícola, v.27, p.639-647, 2007. https://doi.org/10.1590/ S0100-69162007000400006

Orrico Júnior, M. A. P.; Amorim, A. C.; Lucas Júnior, J. de. Biodigestão anaeróbia dos resíduos da produção avícola: Cama de frangos e carcaças. Engenharia Agrícola, v.30, p.546-554, 2010. https://doi. org/10.1590/S0100-69162010000300018

Orrico Júnior, M. A. P.; Amorim, A. C.; Lucas Júnior, J. de. Produção animal e o meio ambiente: Uma comparação entre potencial de emissão de metano dos dejetos e a quantidade de alimento produzido. Engenharia Agrícola, v.31, p.399-410, 2011. https://doi. org/10.1590/S0100-69162011000200020
Quadros, D. G. de; Oliver, A. de P. M.; Regis, U.; Valladares, R.; Souza, P. H. F. de; Ferreira, E. de J. Biodigestão anaeróbia de dejetos de caprinos e ovinos em reator contínuo de PVC flexível. Revista Brasileira de Engenharia Agrícola e Ambiental, v.14, p.326-332, 2010. https://doi.org/10.1590/S1415-43662010000300014

Silva, W. T. L. da; Novaes, A. P. de; Kuroki, V.; Martelli, L. F. de A.; Magnoni Júnior., L. Avaliação físico-química de efluente gerado em biodigestor anaeróbio para fins de avaliação de eficiência e aplicação como fertilizante agrícola. Química Nova, v.35, p.35-40, 2012. https://doi.org/10.1590/S0100-40422012000100007

Yang, L.; Huang, Y.; Zhao, M.; Huang, Z.; Miao, H.; Xu, Z.; Ruan, W. Enhancing biogas generation performance from food wastes by high solids thermophilic anaerobic digestion: Effect of $\mathrm{pH}$ adjustment. International Biodeterioration \& Biodegradation, v.105, p.153-159, 2015. https://doi.org/10.1016/j. ibiod.2015.09.005

Zhai, N.; Zhang, T.; Yin, D.; Yang, G.; Wang, X.; Ren, G.; Feng, Y. Effect of initial $\mathrm{pH}$ on anaerobic co-digestion of kitchen waste and cow manure. Waste Management, v.38, p.126-131, 2015. https://doi. org/10.1016/j.wasman.2014.12.027 